\title{
Diet of two syntopic species of Crenuchidae (Ostariophysi: Characiformes) in an Amazonian rocky stream
}

\author{
Suzanne Fernandes ${ }^{1,2 *}$, Rafael Pereira Leitão ${ }^{3,4}$, Eurizângela Pereira Dary ${ }^{3}$, Ana Isabel Camacho Guerreiro ${ }^{I}$, \\ Jansen Zuanon ${ }^{3}$ \& Cristina Motta Bührnheim² \\ ${ }^{1}$ Instituto Nacional de Pesquisas da Amazonia, Programa de Pós-Graduação em Biologia de água Doce e Pesca de \\ Interior, Manaus, AM, Brazil \\ ${ }^{2}$ Universidade do Estado do Amazonas, Escola Normal Superior, Manaus, AM, Brazil \\ ${ }^{3}$ Instituto Nacional de Pesquisas da Amazônia, Coordenação de Biodiversidade, Manaus, AM, Brazil \\ ${ }^{4}$ Universidade Federal de Minas Gerais, Instituto de Ciencias Biologicas, Departamento de Biologia Geral, Belo \\ Horizonte, MG, Brazil \\ *Corresponding author: Suzanne Fernandes, e-mail: suzanne.bio9@hotmail.com
}

FERNANDES, S., LEITÃO, R.P., DARY, E.P., GUERREIRO, A.I.C., ZUANON, J., BÜHRNHEIM, C., M. Diet of two syntopic species of Crenuchidae (Ostariophysi: Characiformes) in an Amazonian rocky stream. Biota Neotropica. 17(1): e20160281. http://dx.doi.org/10.1590/1676-0611-BN-2016-0281

\begin{abstract}
This study assessed the diet of two poorly known syntopic fish species of the family Crenuchidae, Characidium aff. declivirostre and Leptocharacidium omospilus, in a Presidente Figueiredo' rocky stream, Amazonas, Brazil. The stomach contents were analyzed and their Frequency of Occurrence (FO \%) and Relative Volume (Vol \%) were combined in a Feeding Index (IAi). We examined 20 individuals of $C$. aff. declivirostre and 23 of L. omospilus. The Morisita-Horn Index was used to estimate the overlap between the diets of these species. Immature insects were the most valuable items consumed by both fish species. The diet of $C$. aff. declivirostre was mainly composed of larvae and pupae of Chironomidae, while L. omospilus predominantly consumed larvae of Hydroptilidae, Hydropyschidae and Pyralidae. Thus, both species were classified as autochthonous insectivorous. Characidium aff. declivirostre was considered a more specialized species, probably reflecting lower feeding plasticity or the use of more restricted microhabitats compared to L. omospilus. When the food items were analyzed at the family taxonomic level, the diet overlap between these species was considered moderate (Morisita-Horn Index $=0.4$ ). However, a more thorough analysis, at the genus level, indicates a very low diet overlap. Therefore, we conclude that the feeding segregation between $C$. aff. declivirostre and L. omospilus may favor their co-existence, despite their high phylogenetic closeness.
\end{abstract}

Keywords: stream fish, co-existence, feeding overlap.

\section{Dieta de duas espécies sintópicas de Crenuchidae (Ostariophysi: Characiformes) em um riacho rochoso amazônico}

Resumo: O presente estudo investigou a dieta de duas espécies de peixes pouco conhecidas da família Crenuchidae, Characidium aff. declivirostre e Leptocharacidium omospilus, sintópicas de um riacho de corredeira do município de Presidente Figueiredo, Estado do Amazonas, Brasil. O conteúdo estomacal de cada exemplar foi analisado pelos métodos de Frequência de Ocorrência (FO\%) e Volume Relativo (Vol\%) e, posteriormente, combinados para o cálculo do Índice Alimentar (IAi). Foram analisados 20 indivíduos de C. aff. declivirostre e 23 de L. omospilus. A sobreposição entre a dieta das duas espécies foi estimada pelo Índice Simplificado de Morisita-Horn. Insetos imaturos foram os principais itens consumidos por ambas as espécies. A dieta de $C$. aff. declivirostre mostrou preferência acentuada por larvas e pupas de Chironomidae, enquanto que a dieta de L. omospilus concentrou-se em larvas de Hydroptilidae, de Hydropyschidae e de Pyralidae. Portanto, as espécies foram classificadas troficamente como insetívoras consumidoras de itens autóctones. A dieta de $C$. aff. declivirostre foi mais especializada, o que pode ser reflexo de uma menor plasticidade alimentar ou do uso de microhabitats mais restritos, quando comparado a L. omospilus. Ao analisar os itens alimentares em nível taxonômico de família, a sobreposição alimentar foi considerada moderada (Índice de Morisita-Horn $=0,4$ ). Entretanto, análises mais refinadas, em nível de gênero, indicaram sobreposição muito baixa na dieta. Conclui-se que tal segregação alimentar pode favorecer a coexistência de $C$. aff. declivirostre e L. omospilus, mesmo que sejam espécies filogeneticamente próximas.

Palavras chaves: Peixes de riacho, coexistência, sobreposição alimentar. 


\section{Introduction}

The co-existence of species can be affected by their ecological niche, characterized by their diet and feeding tactics, habitat preferences, reproductive strategy, and period of activity (Hutchinson 1957). However, species with similar ecological demands (e.g., phylogenetically closely related species) might not coexist during conditions of resource limitation, because the less competitive would inevitably become extinct as defended by the theory of limiting similarity (Mac Arthur \& Levins 1967) and by the competitive exclusion principles (Hardin 1960). Schoener (1974) studied the trophic relationship between syntopic species and proposed three conditions that would allow the co-existence of related species: (1) species may explore distinct microhabitats, (2) they have different diel habits, or (3) they consume distinct food items. Thus, feeding studies can be used as a valuable data source for ecological modelling research, and for the better understanding of syntopic species interaction (Schoener 1974).

Fish feeding studies in small Amazonian streams began during the 1970s (regionally called "igarapés")(e.g., Knöppel 1970, Soares 1979), and were intensified after that (e.g., Silva 1993, Sabino \& Zuanon 1998, Anjos 2005, Carvalho 2008, Zuanon \& Ferreira 2008, Fernandes 2014; Barros et al. 2017). However, such information is still restricted to those streams with the typical regional geomorphology found in the Central Amazonia (i.e., with low declivity, sandy bed, the presence of stems, roots and a thick layer of humus) (Walker 1995, Mendonça et al. 2005). Moreover, few studies have been developed in areas of waterfalls and river rapids (Zuanon 1999), and to our knowledge, no studies were carried out about fish diet and resource partitioning in rapids with stony riverbed.

The region of Presidente Figueiredo is located at the southern boundary of the Guianas' shield and is characterized by rocky streams with long rapids and waterfalls (Nogueira \& Sarges 2001). Moreover, studies that are being developed in rocky streams of this same region have already recorded a high co-occurrence of two rheophilic species of the subfamily Characidiinae: Characidium aff. declivirostre Steindachner, 1915 and Leptocharacidium omospilus Buckup, 1993 (R.P. Leitão, unpublished data) (Figure 1).To maintain their spatial position over the rocky substratum, to find and catch preys as well as interact with individuals of the same and other species, morphological and behavioral adaptations may occur in species that inhabit high-speed rapids. Thus, our aims were to determine the diet of Characidium aff. declivirostre and Leptocharacidium omospilus as well as to investigate the degree of interspecific overlapping in this niche dimension.

\section{Material and Methods}

\section{Study Area}

This study was developed in Marupiara' rocky stream $\left(2^{\circ} 3\right.$ ' 15.41 'S; $60^{\circ} 6$ '21.72'W), a second-order stream of Urubu River, which flows into the left margin of Amazon River, municipality of Presidente Figueiredo (Amazonas, Brazil). Marupiara' stream is characterized by long rapids with stony bed, low depth $(3-70 \mathrm{~cm})$, narrow width (4.8 $\mathrm{m}$ on average), clear and acidic waters with high levels of oxygen, and surrounded by partially intact old-growth forest (Figure 2).

\section{Data collection}

Specimens of Characidium aff. declivirostre and Leptocharacidium omospilus were collected between June and December of 2009, and also in March of 2011 during the daytime, using small dip nets (1 mm mesh). The collected specimens were anaesthetized with Eugenol and fixed in 10\% formaldehyde. Voucher specimens were deposited in the fish collection of the Instituto Nacional de Pesquisas da Amazônia (INPA33926, 33927, 33928, 33929), Brazil.

\section{Data analysis}

Stomach content of 20 adult individuals of Characidium aff. declivirostre (40.3 - $73.0 \mathrm{~mm}$ in standard length SL) and 23 of Leptocharacidium omospilus (40.0 - $68.5 \mathrm{~mm} \mathrm{SL})$ were analyzed using a stereoscopic microscope. Food items were identified to the lowest possible taxonomic level with the aid of specialised literature. Moreover, the degree of repletion was visually estimated (as the amount of food by stomach expressed in percentage) (adapted from Goulding et al. 1988).

Stomach contents were analyzed according to the methods of Frequency of Occurrence (FO\%) (Hyslop 1980) and Relative Volume (Vol \% = volume of a given food item/ volume of the stomach). To correct values with distinct amount of aliment, the relative volume was multiplied by the respective degree of stomach repletion (Soares 1979). Finally, the Feeding Index (IAi) was computed using the results previously provided from the determination of the frequency of occurrence as well as the percentage of volume (Kawakami \& Vazzoler 1980). The Feeding Index determines the effective importance of each item found in species feeding and contributes to the analysis of the species feeding overlap (Kawakami \& Vazzoler 1980).
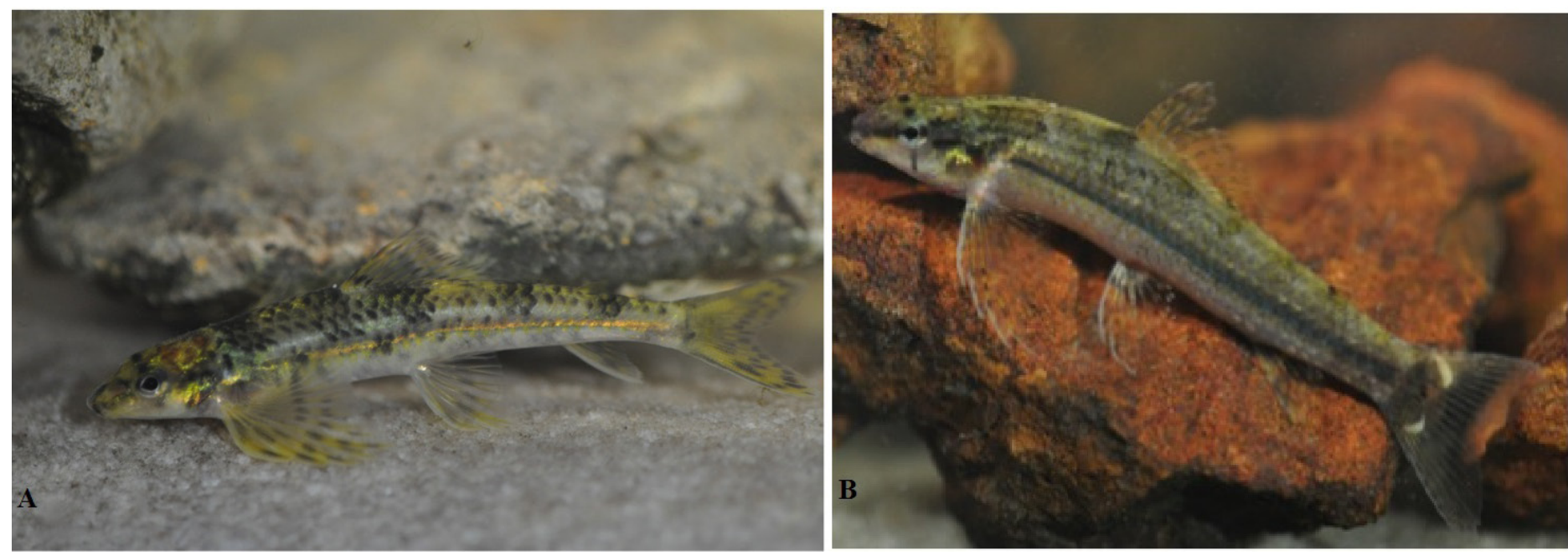

Figure 1: Characidium aff. declivirostre (A) and Leptocharacidium omospilus (B) specimens caught in Marupiara'rocky stream, Presidente Figueiredo - Amazonas, Brazil. Photos taken in aquaria by R. P. Leitão. 
The Feeding Index is determined by the equation: $I A i=\mathrm{Fi} \times \mathrm{Vi} \sum(\mathrm{Fi} \times \mathrm{Vi})$. Where, $\mathrm{F}_{i}=$ Frequency of occurrence $(\%)$ of item $\mathrm{i} ; \mathrm{V}_{i}=$ relative volume (\%) of item $i$.

To assess the degree of diet overlap between the fish species, we used the Morisita-Horn Index $\left(C_{H}\right.$; Horn 1966, Krebs 1998), determined by the equation: $C_{H}=2 \sum_{\mathrm{i}}^{\mathrm{n}} \mathrm{pij} \times \mathrm{pik} / \sum^{\mathrm{n}}{ }_{\mathrm{i}} \mathrm{p}^{2} \mathrm{ij}+\sum_{{ }_{\mathrm{i}}}^{\mathrm{n}} \mathrm{p}^{2} \mathrm{ik}$. Where, $\mathrm{p}_{i j}=$ proportion of item $i$ relative to the total resources used by species $j ; p_{i k}=$ proportion of item $i$ relative to the total resources used by species $k ; n=$ total number of resource items. $C_{H}$ ranges from 0 (no food items shared) to 1.0 (complete overlap), with values $>0.6$ indicating significant overlap (Richard \& Wallace 1981). This analysis was based on the taxonomic levels of family and genus for the consumed items.
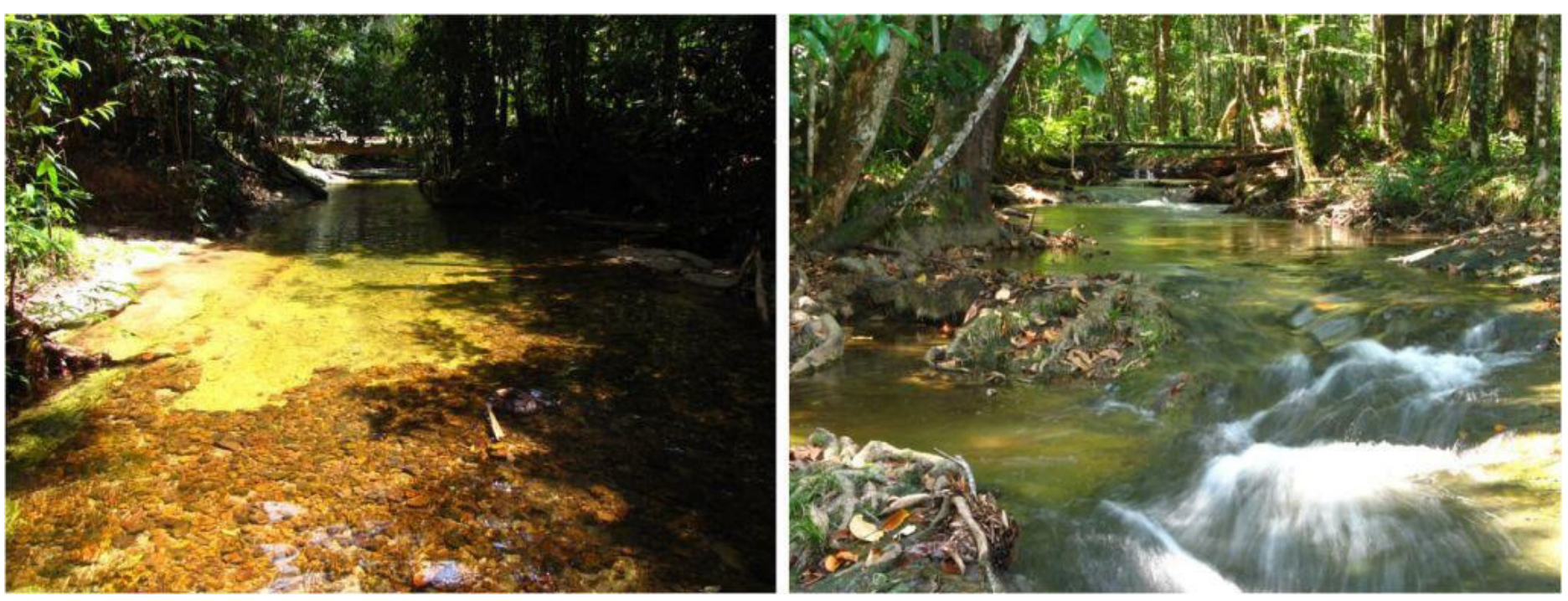

Figure 2: Marupiara' rocky stream, Presidente Figueiredo - Amazonas, Brazil. The samples were collected along stretch between less turbulent waters with dominance of released stones (left) and more turbulent waters with slabs of rock (right).

Table 1: Values of Frequency of occurrence (FO \%), Relative volume (Vol \%) and Feeding Index (IAi) for each of the food items consumed by Characidium aff. declivirostre and Leptocharacidium omospilus. $1=$ larvae, $\mathrm{p}=$ pupae, $\mathrm{n}=$ nymph, $\mathrm{a}=$ adult

\begin{tabular}{|c|c|c|c|c|c|c|c|}
\hline \multirow{2}{*}{ Items } & \multirow{2}{*}{ Origin } & \multicolumn{3}{|c|}{ Characidium aff. declivirostre $(\mathrm{n}=17)$} & \multicolumn{3}{|c|}{ Leptocharacidium omospilus $(\mathrm{n}=13)$} \\
\hline & & FO\% & Vol\% & IAi*100 & FO\% & Vol\% & IAi*100 \\
\hline Chironomidade $(1+p)$ & \multirow{18}{*}{ autochthonous } & 100.00 & 33.68 & 49.03 & 69.23 & 2.40 & 3.80 \\
\hline Simulidae (1) & & 17.65 & 3.55 & 0.91 & 15.38 & 1.65 & 0.58 \\
\hline Empidae (1) & & 23.53 & 0.95 & 0.33 & - & - & - \\
\hline Tipulidae (1) & & 5.88 & 1.78 & 0.15 & - & - & - \\
\hline Ceratopogonidae (1) & & 5.88 & 0.57 & 0.05 & 7.69 & 0.24 & 0.04 \\
\hline Hydropyschydae (l) & & 17.65 & 2.44 & 0.63 & 38.46 & 28.57 & 25.14 \\
\hline Odontoceridae (1) & & - & - & - & 7.69 & 0.65 & 0.11 \\
\hline Hydroptilidae (1) & & 88.24 & 15.62 & 20.05 & 61.54 & 19.00 & 26.76 \\
\hline Elmidae $(1+a)$ & & 17.65 & 0.95 & 0.24 & 23.08 & 2.29 & 1.21 \\
\hline Pyralidae (1) & & 41.18 & 11.33 & 6.79 & 38.46 & 22.82 & 20.08 \\
\hline Baetidae (n) & & 52.94 & 22.8 & 17.57 & 30.77 & 6.92 & 4.87 \\
\hline Leptohyphydae (n) & & 5.88 & 0.04 & 0.00 & - & - & - \\
\hline Leptophlebiidae(n) & & - & - & - & 15.38 & 0.90 & 0.32 \\
\hline Caenidae (n) & & - & - & - & 7.69 & 1.29 & 0.23 \\
\hline Megaloptera (1) & & - & - & - & 7.69 & 0.32 & 0.06 \\
\hline Colopterygidae (n) & & - & - & - & 7.69 & 0.39 & 0.07 \\
\hline Perlidae (n) & & 5.88 & 0.14 & 0.01 & - & - & - \\
\hline Algae & & 5.88 & 0.38 & 0.03 & - & - & - \\
\hline Plant material & \multirow{2}{*}{ alloctone } & 23.53 & 0.41 & 0.14 & 7.69 & 0.48 & 0.09 \\
\hline Acari & & 35.29 & 0.24 & 0.12 & 23.08 & 0.38 & 0.20 \\
\hline Organic debris & unidentified & 52.94 & 5.12 & 3.94 & 61.54 & 11.68 & 16.45 \\
\hline
\end{tabular}


The diet of Characidium aff. declivirostre was composed of 16 food items, and the most representative (i.e., with the highest IAi values) were: larvae and pupae of Chironomidae (49.02\%), shelters and larvae of Hydroptilidae (20.05\%), and nymphs of Baetidae (17.56\%) (Table 1 and Figure 3). Moreover, Leptocharacidium omospilus also consumed 16 food items, and the most relevant items were: larvae of Hydroptilidae (26.75\%), larvae of Hydropyschydae (25.13\%), larvae of Pyralidae $(20.07 \%)$ and organic debris (16.44\%) (Table 1 and Figure 3). Overall, food items were more equally distributed in $L$. omospilus than in $C$. aff. declivirostre, as a clear predominance of one food category was observed for $C$. aff. declivirostre (Figure 3).

Based on the Morisita-Horn Index applied to the taxonomic level of family of the consumed items, a moderate degree of diet overlap was detected between the two syntopic species $\left(C_{H}=0.4\right)$. However, given the great importance of Hydroptilidae for the diet of both fish species, we conducted a more thorough analysis by identifying and quantifying the different genera of this family. This analysis revealed a clear difference between the proportions of each item consumed by the crenuchids. For example, the genus Anchitrichia composed almost half of Hydroptilidae $(\mathrm{Vol}=$ $47 \%$ ) found in $C$. aff. declivirostre diet, but it was not observed in the diet of L. omospilus (Figure 4). On the other hand, the genus Neotrichia represented more than $70 \%$ of Hydroptilidae consumed by L. omospilus, but only $6 \%$ of Hydroptilidae consumed by $C$. aff. declivirostre (Figure 4 ).

\section{Discussion}

The diet of Characidium aff. declivirostre and Leptocharacidium omospilus is mainly composed of aquatic or terrestrial insects in its aquatic phase. Therefore, we may categorize both species as autochthonous insectivores. Similar results have been found by other diet studies developed with species of the same sub-family such as, Characidium sp., C. lanei, C. pterostictum and C. vidali (in streams of Atlantic Forest: Sabino \& Castro 1990, Aranha et al. 2000, Rezende et al. 2013), C. pteroides and Characidium sp. (in Amazonian streams: Anjos 2005, Carvalho 2008).

The great variety of preys ingested by both species suggests that they are generalist feeders. However, given the high proportion of a single family of insects (Chironomidade: $49.02 \%$ ) in its diet, $C$. aff. declivirostre has also shown some tendency to specialization. This may be due to ecological causes associated with the Optimal Foraging Theory as many generalist populations could be composed by individuals with tendency to
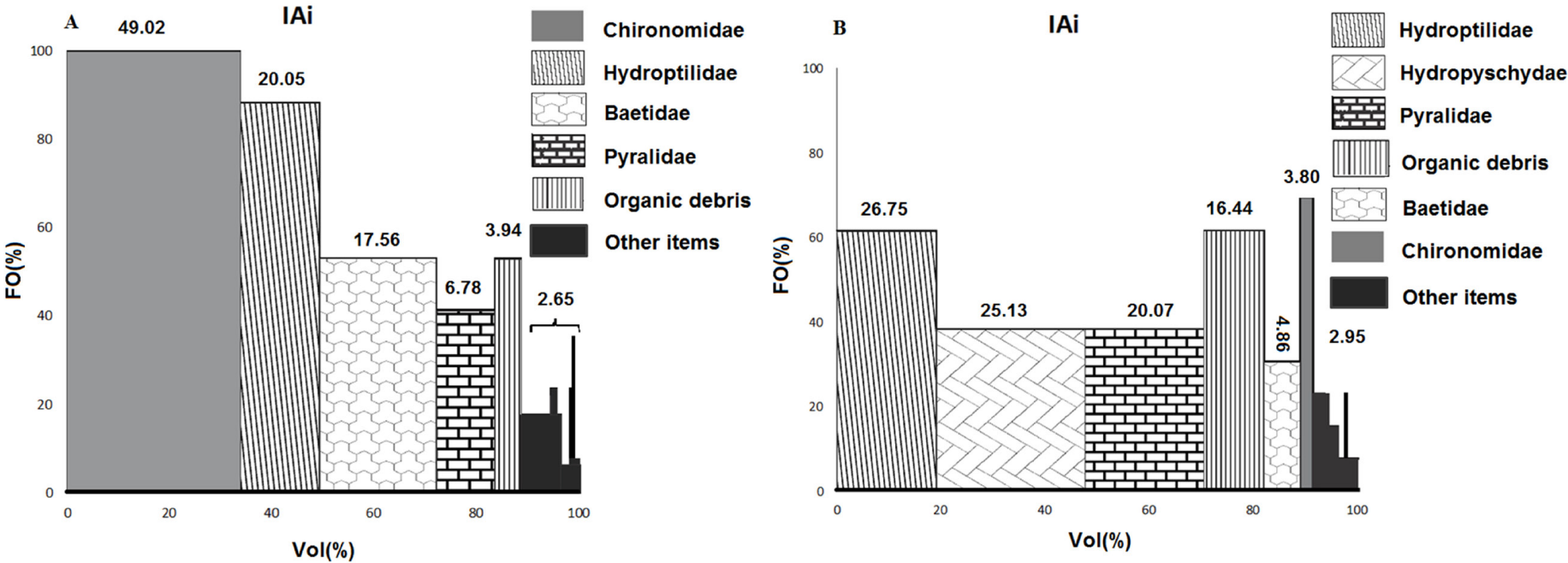

Figure 3: Frequency of occurrence (FO \%) and Relative volume (Vol \%), for the food items consumed by Characidium aff. declivirostre (A) and Leptocharacidium omospilus (B).

\section{Characidium aff. declivirostre}

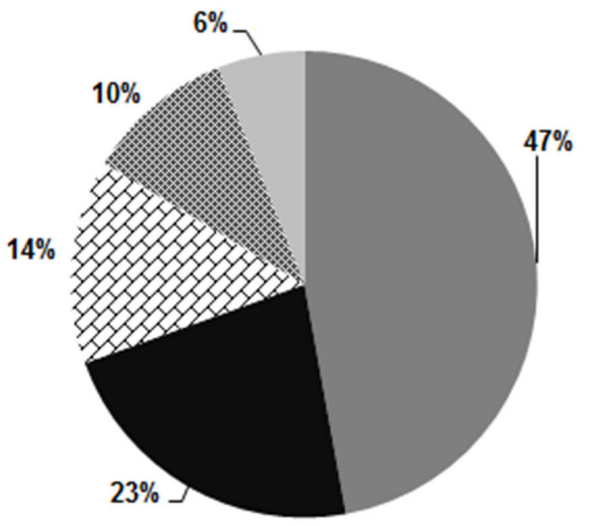

\section{Leptocharacidium omospilus}

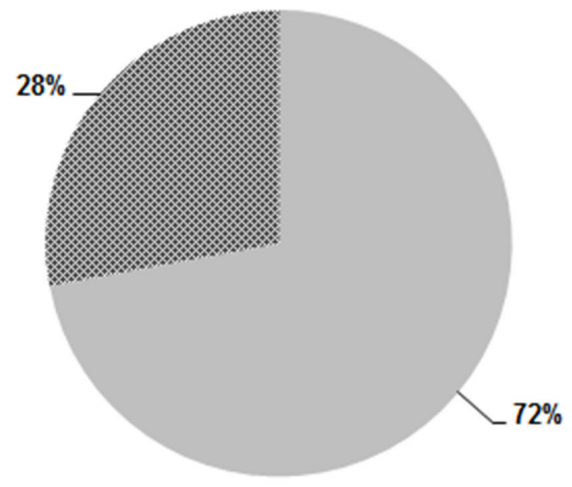

Neotrichia

: Leucotrichia

Figure 4: Family Hydroptilidae - Relative volume (\%) of genera identified for Characidium aff. declivirostre and Leptocharacidium omospilus. 
specialization (Araújo et al. 2011). The generalist strategy here observed may be favored by the typical seasonality of prey availability found in Neotropical streams (Gerking 1994, Zuanon \& Ferreira 2008). Indeed, many of the stream fishes have already been categorized as generalists, consuming the most abundant resources available in their habitats (Esteves \& Aranha 1999). The results found in this study were not an exception, in fact, the vast abundance of larvae and pupa of Dipterans detected seem to support such information as they also use to be well represented in rapids (Carvalho 2008, Hamada et al. 2014). Great abundance and richness of aquatic insects such as larvae of Trichoptera ( 32 genera and 11 families) have also been recorded for the rocky streams of Presidente Figueiredo (Pes 2001). Therefore, and also according to the Optimal Foraging Theory, generalist strategy may be favored because the ingestion of the most available preys will represent a reduction in energy costs when searching and selecting them (Stephens \& Krebs 1986).

Many aquatic insects found in the diet of both fish species (e.g., Simulidae, Hydroptilidae and Baetidae) have morphological and physiological characteristics that allow them to remain in fast-flowing waters (Hamada et al. 2014). For example, larvae of Simulidae have adhesive hooks that efficiently adhere to the substratum surface, and larvae of Hydroptilidae attach its shelters to large pieces of submerged wood (Hamada et al. 2014). Thus, here we show evidences that $C$. aff. declivirostre and L. omospilus are foraging in fast-flowing and turbulent rapids.

Based on the Morisita-Horn Index applied to the taxonomic level of family of the consumed items, a moderate degree of diet overlap was detected between the two syntopic species. This is probably explained by the similar overall composition of items, although the amount of each item is quite distinct between $C$. aff. declivirostre and L. omospilus. A more in-depth assessment of one of the most important prey families (the Hydroptilidae) has shown a very distinct contribution of genera between species diets. Therefore, despite $C$. aff. declivirostre and $L$. omospilus being phylogenetically related species, living in the same habitat, they seem to be, at least partly, segregating its niche dimension (i.e., diet).

Meanwhile, high feeding overlap has been extensively registered between closely related species, and the spatial segregation (e.g., meso or microhabitats) was considered as the most important partitioning mechanism (Schoener 1974, Aranha et al. 1998, Aranha et al. 2000, Mazzoni et al. 2012, Silva et al. 2012, Leitão et al. 2015, Barros et al. 2017).In Amazonian streams, high dietary overlap (60\%) was registered between syntopic characids (Bryconops inpai and B. giacopinii), but they were occupying distinct positions in the water column (Barros et al. 2017). Furthermore, competition between species with similar dietary habits would also be reduced by the high amount of preys found in this same area (Knoppel 1970). However, the few studies developed in Amazonian streams were restricted to those streams with geomorphology typical of the region (i.e., low declivity and current velocity, sandy bottom with trunks and a dense layer of humus) (Santos 2005, Fernandes 2014, Barros et al. 2017). Streams with more homogenous and continuous rocky bottom (i.e., slab) with strong currents, as those of Presidente Figueiredo region, may offer less feeding opportunity and great difficulty of swimming and fish positioning along the water column. So, the co-existence of $C$. aff. declivirostre and L. omospilus may be favored by their partial partitioning of resources that probably is also reducing the competition between them (Pianka 1973, Schoener 1974). Notwithstanding, further studies on other niche dimensions, such as the use of microhabitats, are certainly desirable to a better elucidation of the mechanisms promoting their co-occurrence in these streams.

Fish feeding studies are crucial for several theoretical and practical aspects. Regardless of the vast biodiversity of Amazonia, such approach is still rare for stream systems. Particularly for rocky streams with rapids, this is the first study that aimed to investigate the fish diet and the importance of such niche dimension for explaining species co-existence, being an important basis for the knowledge of the natural history of the Amazonian ichthyofauna.

\section{Acknowledgments}

We thank Ana Pes, Cristhiana Ropke and Carolina Pádua for helping with the identification of the food items; Rodrigo Neves for the macroscopic analysis of the gonads; Daniele Kasper, Gabriel Cardoso, Helder Espírito-Santo and Marla Carvalho for the fish collection; and Marupiara farm for logistic support. Financial support was provided by CNPq and FAPEAM. This is contribution \#48 of the Projeto Igarapés.

\section{References}

ANJOS, M.B. 2005. Estrutura de comunidades de peixes de igarapés de terra firme na Amazônia Central: composição, distribuição e características tróficas. Dissertação de Mestrado. Instituto Nacional de Pesquisas da Amazônia/ Universidade Federal do Amazonas, Manaus, Amazonas.

ARAÚJO, M.S., BOLNICK, D.I. \& CRAIG, A.L. 2011. The ecological causes of individual specialization. Ecology Letters, 14:948-958.

ARANHA, J.M.R., GOMES, J.H. \& FOGAÇA, F.N.O. 2000. Feeding of two sympatric species of Characidium, C. lanei and C. pterostictum (Characidiinae) in a coastal stream of Atlantic Forest (Southern Brazil). Brazilian Archives of Biology and Technology, 43 (5): 527-531.

ARANHA, J.M.R., TAKEUTI, D.F. \& YOSHIMURA, T.M. 1998. Habitat use and food partitioning of the fishes in a coastal stream of Atlantic Forest, Brazil. Revista de Biología Tropical, 6: 955-963.

BARROS, G., ZUANON, J. \& DEUS, C. 2017. Effects of species co-occurrence on the trophic-niche breadth of characids in Amazon forest streams. Journal of Fish Biology, 90: 326-340.

CARVALHO, L.N. 2008. História Natural de peixes de igarapés amazônicos: utilizando a abordagem do Conceito do Rio Contínuo. Tese de Doutorado. Instituto Nacional de Pesquisas da Amazônia.

ESTEVES, K.E. \& ARANHA, J.M.R. 1999. Ecologia trófica de peixes de riachos. In: CARAMASCHI, E.P., MAZZONI, R. e PERES-NETO, P.R., eds. Oecologia Brasiliensis: Ecologia de peixes de riachos(vol. VI). Rio de Janeiro: PPGE Universidade Federal do Rio de Janeiro, p.157-182.

FERNANDES, S.S. 2014. Relações tróficas entre três espécies sintópicas de Rivulus (Cyprinodontiformes: Rivulidae) em igarapés da Reserva Ducke, Manaus, Amazonas. Dissertação Mestrado. Instituto Nacional de Pesquisas da Amazônia.

GERKING, S.D. 1994. Feeding ecology of fish. Califórnia: Academic Press. 416p.

HORN, H.S. 1966. Measurement of “overlap" in comparative ecological studies. The American Naturalist 100: 419-424.

GOULDING, M., CARVALHO, M. L. \& FERREIRA, E.G. 1988. Rio Negro, rich life in poor water. SPB Academic, The Hague, Netherlands.

HAMADA, N., NESSIMIAN, J.L. \& QUERINO, R.B. 2014. Insetos aquáticos na Amazônia brasileira: taxonomia, biologia e ecologia. Manaus: Editora do INPA.

HARDIN, G. 1960. The Competitive Exclusion Principle. Science, New Series, 131(3409):1292.

HYSLOP, E.J. 1980. Stomach contents analysis- a review of methods and their application. Journal of Fish Biology, 17:411-429.

HORN, H.S. 1966. Measurement of "overlap" in comparative ecological studies. The American Naturalist, 100:419-424.

HUTCHINSON, G.E. 1957. Concluding remarks. Cold Spring Harbor Symposium on Quantitative Biology, 22:415-427.

KAWAKAMI, E. \& VAZZOLER, G. 1980. Método estimativo de índice de importância alimentar aplicado no estudo de alimentação de peixes. Bolm Instituto de Oceanografia. São Paulo, 29 (2): 205-207.

KNÖPPEL, H.A. 1970. Food of Central Amazonian Fishes: Contribution to the nutrient-ecology of Amazonian rain-forest-streams. Amazoniana, 2 (3):257-352.

LEITÃO, R.P., SÁNCHEZ-BOTERO, J.V., KASPER, D., TRIVÉRIO-CARDOSO, V., ARAÚJO, C.M., ZUANON, J. \& CARAMASCHI, E.P. 2015. Microhabitat segregation and fine ecomorphological dissimilarity between two closely 
phylogenetically related grazer fishes in an Atlantic Forest stream, Brazil. Environmental Biology of Fishes, 98 (9): 2009-2019.

MACARTHUR, R. \& LEVINS, R. 1967. The Limiting Similarity, Convergence, and Divergence of Coexisting Species. The American Naturalist, 101 (921): 377-385.

MAZZONI, R., MARQUES, P.S., REZENDE, C.F. \& IGLESIAS-RIOS, R. 2012. Niche enlargement as a consequence of co-existence: a case study. Brazilian Journal of Biology, 72 (2): 267-274.

MENDONÇA, F.P., MAGNUSSON, W.E. \& ZUANON, J. 2005. Relationships between Habitat Characteristics and Fish Assemblages in Small Streams of Central Amazonia. Copeia, 4:750-763.

NOGUEIRA, A.C.R. \& SARGES, R.R. 2001. Characterization and genesis of waterfalls of the Presidente Figueiredo region, northeast State of Amazonas, Brazil. Anais da Academia Brasileira de Ciências, 73(2): 287-301.

PES, A.M.O. 2001. Taxonomia e estrutura de comunidade de Trichoptera (Insecta) no município de Presidente Figueiredo, Amazonas, Brasil. Dissertação de mestrado. Instituto Nacional de Pesquisas da Amazônia.

PIANKA, E.R. 1973. The structure of lizard communities. Annual Review of Ecology and Systematics, 4:53-74.

REZENDE, C.F., LOBÓN-CERVIÁ, J., CARAMASCHI, E.P. \& MAZZONI, R. 2013. Trophic ecology of two benthivorous fishes in relation to drift and benthos composition in a pristine Serra do Mar stream (Rio de Janeiro, Brazil). Fundamental and Applied Limnology, 183 (2): 163-175.

RICHARD, K. \& WALLACE, JR. 1981. An Assessment of Diet-Overlap Indexes. Transactions of the American Fisheries Society, 110:72-76.

SABINO, J. \& CASTRO, R.M.C. 1990. Alimentação, período de atividade e distribuição espacial dos peixes de um riacho da floresta Atlântica (Sudeste do Brasil). Revista Brasileira de Biologia, 50: 23-36.

SABINO, J. \& ZUANON, J. 1998. A stream fish assemblage in Central Amazonia: distribution, activity patterns and feeding behavior. Ichthyological Exploration of Freshwaters, 8 (3): 201-210.
SANTOS, S.M. 2005. Relações tróficas entre Carnegiella marthae Myers 1927, C. strigata (Günther, 1864) e Gnathocharax steindachneri Fowler, 1913 (Ostheichthyes: Characiformes) em igarapés próximos ao lago Amanã, Amazonas, Brasil. Dissertação de mestrado. Instituto Nacional de Pesquisas da Amazônia.

SCHOENER, T.W. 1974. Resource partitioning in ecological communities. Science, 185:27-38.

SILVA, J.C., DELARIVA, R.L. \& BONATO, K.O. 2012. Food-resource partitioning among fish species from a first-order stream in northwestern Paraná, Brazil. Neotropical Ichthyology, 10(2): 389-399.

SILVA, C. 1993. Alimentação e distribuição espacial de algumas espécies de peixes do igarapé do Candiru, Amazonas, Brasil. Acta Amazonica, 23 (2-3): 271-285.

SOARES, M.G.M. 1979. Aspectos ecológicos (alimentação e reprodução) dos peixes do igarapé do Porto, Aripuanã, MT. Acta Amazonica, 9: 325-352.

STEPHENS, D.W. \& KREBS, J.R. 1986. Foraging Theory, Princeton University Press, Princeton.

WALKER, I. 1995. Amazonian streams and small rivers. In: TUNDISI, J.G., BICUDO, C.E.M., MATSUMURA-TUNDISI, T. (Eds). Limnology in Brazil. Soc. Bras. De Limnologia/Acad. Bras. de Ciências, p. 167-193.

ZUANON, J. \& FERREIRA, E. 2008. Feeding ecology of fishes in the Brazilian Amazon - a naturalistic approach. In J.E.P. Cyrino, D. Bureau and B.G. Kapoor (Eds.). Feeding and Digestive Functions of Fishes. Science Publishers, Inc., USA.

ZUANON, J.A.S. 1999. História natural da ictiofauna de corredeiras do rio Xingu, na região de Altamira, Pará. Tese de Doutorado. Universidade Estadual de Campinas.

Received: $21 / 10 / 2016$

Revised: 25/01/2017

Accepted: 23/02/2017

Published online: 27/03/2017 